\title{
Address Pronouns Revisited: A Case of Theatre and Translation Pragmatics
}

\author{
Alba Graziano
}

\begin{abstract}
After an overview of the general scholarship both on the uses of the second person singular pronouns in Early Modern English (EME) and on the contrast between English and the so-called "T/V" languages (such as Italian) in terms of translation issues, this article focuses on Restoration comedy. Some observations on modern Italian translations (even in the absence of explicit indications by the translators) lead to a case study drawn from a personal experience as the translator of Aphra Behn's Sir Patient Fancy, which will serve to illustrate the performative force exerted by address pronouns on the stage and the impact on both academic and dramaturgical renderings of comedic texts.
\end{abstract}

\section{Keywords}

Restoration comedy, drama translation and performance, address pronouns, Aphra Behn, Sir Patient Fancy 
It is in the intentions of this contribution to tackle a single national context and to focus on an apparently circumscribed linguistic phenomenon as it manifests itself in a less known Restoration comedy in order to draw some conclusions of general interest about drama translation (if not translation at large). The long-standing and worldwide practice of drama in translation, beside its relevance to theatre studies, can be justly considered a crucial chapter of international relationships, even in the political sense, as shown by the reciprocal influences and by the competition for the spectacular display of power in the age of royal absolutisms. Since theatre remains part of an oral and popular tradition, translated drama becomes an arena of cultural, linguistic and technical interpretations and hybridizations that imply something more than "simply" studying the reception of literary works, authors or movements in different socio-cultural contexts. We share the feeling of this journal's editors that drama in translation should find a much more scientifically solid and stable place in the study of historic drama with the effect of inspiring more conscious readings and translations and we hope to be part of this process.

\section{Translating Restoration comedies in Italy}

In comparison to the overwhelming amount of scholarship devoted to Elizabethan, Jacobean and Caroline drama and the unceasing presence of Shakespeare in theatres of all sorts, Restoration drama has received very limited attention in Italy, from all three relevant viewpoints: theatrical performance, critical interpretation and dissemination through translations. A slightly better fate has been reserved for the two main and most prolific authors of the period, Aphra Behn and John Dryden, and to comedy (the focus of this article), among the numerous genres and subgenres comprising the huge corpus of this theatre, especially in terms of the longest chronology - 1660-1737 - as in the scope of this special issue. ${ }^{1}$

To survey the reception of Restoration comedy in contemporary Italy through the lens of translation, a corpus of comedic texts must be delimited. The collection of plays contained in The Broadview Anthology of Restoration and Early Eighteenth-Century Drama, edited by Canfield (CANFIELD 2001) and inspired by his taxonomy (CANFIELD 1997), ${ }^{2}$ is invaluable in helping to circumscribe the corpus of Italian translations

1 Periodization debates are not as pursued nowadays as they used to be. Eighteenth-century scholars might raise an eyebrow at such an extension far into the 1700s: however, the idea of a Long Restoration has recently provided an alternative to the Long Eighteenth Century (HOBBY 2007). At the other end of the period, a deep divide between the pre-Commonwealth scene and Restoration drama due to the closure of the public theatres cannot be seriously defended (see, among others, RANDALL 1995). As for comedy, any qualitative differentiation based on crossing a division of the long chronology in three historical blocks - i.e., actual Restoration (1660-1688), (Glorious) Revolution (1689-1714), Early Georgian (1715-1737) - and the repertoires which supposedly developed different comic subgenres in time - political and satirical comedy, Spanish comedy, London comedy, farce, sex comedy, comedy of manners, etc. - appears to be decidedly idle.

2 Douglas Canfield's critical work, based on Christopher Hill's historiography, Raymond Williams's The Country and the City, Mikhail Bakhtin's interpretation of the comic spirit and Michel Foucault's critique of ide- 
and adaptations for performance, too. Mainly focusing on social and subversive comedies, which constitute the bulk of the Long Restoration comedy, specimens of neighbouring subgenres (i.e., tragicomic romance, corrective and Menippean satire) are included, given the notoriety of the authors representing such categories (Behn, Dryden, Otway) and their subsequent presence in Italy. ${ }^{3}$

The two surveys carried out on the literary/academic translations and on the stage performances and corresponding translations for adaptation (tradaptations, as in BASTIN 1998) lead to provisional conclusions, which still require further evidence. ${ }^{4}$ However, the fortune of Restoration comedy texts in Italy after World War II seems to rely:

1) on 25 book editions, mainly of academic origin, starting in 1955 but concentrated in the 1960s and 1990s with a resurgence in the new millennium and mainly reproducing the same comedies: The Country Wife - translated up to four times - The Way of the World (3×), The Man of Mode (3×), The Rover (3×), The Beaux' Stratagem $(2 \times)$, Love for Love $(2 \times)$, and The Beggars' Opera $(2 \times) ;{ }^{5}$ and

2) on a handful of performances (I have traced 21 thus far), yet including some surprises, such as a reversal in the number of performances of the same play compared to the book editions (with The Beggar's Opera, The Beaux' Stratagem and The Way of the World leading the shortlist), the staging of less canonical plays (e.g., The Recruiting Officer and The Twin Rivals, both by Farquhar) and a number of radio and TV adaptations.

ology, offers an excellent key to understand the simultaneously cultural and linguistic intervention of comedy in the Restoration context by extolling its political ethos, at times sheer propaganda, where human relationships, sentiments and, more interestingly to us, communication revolve around the two socio-economic and legal axes of matrimony and patrimony. Moreover, it supports a convincing typology which groups the plays by identifying on the one hand a majority of social comedy and on the other only a few specimens or parts, sections, and characters defined as subversive comedy. The first one stages, albeit through infinite nuances, the classical skirmishes between the young heiress - beautiful, witty and coy - and her gallants - handsome, careless and penniless - a contrast which normally results in a happy ending, thus celebrating the harmonization of economic interests and hereditary genealogy around the institution of marriage. This in turn strengthens the self-image of the pro-tempore winning party, the Royalist, as opposed to the Parliamentary, Puritan, and City middle class, and sanctions its supremacy while at the same time exorcising the endemic danger of plots and coups d'état with satire, deception and trickery. The other line, a minority one, albeit relying on samples such as The Country Wife, is radically antithetical to the ideological naturalization of aristocracy as the only ruling class thanks to divine hereditary right. Subversion is played through a direct attack on hereditary genealogy by threatening to lead libertinism to extremes, or as Canfield very wittily used to say, the scrambled eggs of adultery and the jumbled genealogy of mixed progeny (e.g., The Careless Lovers). This taxonomy has the advantage of cutting across chronology, since examples of both categories appear all along shedding light on the high degree of conflict in the Restoration age (between genders, social classes, political factions and even races) and on the staging of these conflicts through plot and dramatic dialogue in the comedies.

3 For example, translations or adaptations of Otway's Venice Preserved, normally classified as a tragedy, are also included, because it is considered Menippean satire in The Broadview Anthology and because it is quite present in the Italian panorama, possibly due to its Venetian setting.

4 Due to the difficulties involved in library and archive consultation during COVID times, research on drama, radio and TV tradaptations remains ongoing. However, some interesting interim results have already emerged from cross-checking data from OPAC SBN (national book catalogue), the archives of SIAE (Società Italiana Autori e Editori), RAI Teche, the catalogues of the Turin Teatro Stabile and an Internet search of translators' profiles.

5 In most cases these editions are by now out of print or rare books. 
The general impression derived from the early stages of this survey is that over the years the translations for performance have been by non-academics, even when academic translations existed, and have often been carried out by the same stage directors or by professional translators involved in the process of theatre/screen/radio adaptation and adjustment at different levels. ${ }^{6}$ Apparently, despite well-known instances of cooperation between some of the most relevant Italian stage directors and scholars of the Shakespearean text, ${ }^{7}$ a more multidisciplinary concept of theatre translation, which we are starting to call dramaturgical translation, has not joined the two worlds in the common cause of promoting Restoration comedies. ${ }^{8}$

The debate surrounding drama translation has been ongoing for decades: the positions of its protagonists (Bassnett, Pavis, Aaltonen, Ubersfeld, Serpieri, Johnston, SnellHornby, Upton and Pym, to name only a few of the most prominent ones) have been thoroughly illustrated in many essays (among them NIKOLAREA 2002; FERNANDES 2010; SUH 2011). One can follow the evolution of the debate from the polarization between the supposedly opposite dimensions of text and performance, page and stage, readability and performability, even theatre and performance, with a range of philosophical overtones (subject/object, absence/presence, universal/context-driven), down to a pervasive "performative turn" in cultural and translation studies. This has undoubtedly "enlarged paradigms", appreciated the practitioners' contribution, introduced the idea of multilingualism/multiculturalism and reshaped the figure of the translator as collaborator and even co-author in the actualization of the theatrical text. Yet, as BIGLIAZZI et al. (2013) very insightfully point out, even the idea of "cooperative translation" is fraught with the risk of blurring the specific roles involved in theatre production in a socio-economic context which already tends to depreciate the high competencies implied by literary (and non-literary) translation.

In the end, one may agree with Soncini's role distinction:

6 I have found only three exceptions: The Way of the World / Cosi va il mondo: Commedia in cinque atti, translation by Giorgio Melchiori, radio adaptation for channel RF3 RAI 26/11/1958, directed by Mario Ferrero; The Rover / Cavalieri senza patria, tradaptation by Giuseppe D'Agata \& Viola Papetti for the company "Il cerchio di gesso", 1982, directed by Ugo Gregoretti; and The Country Wife / La sposa di campagna, translation by Masolino D'Amico for Centro Teatrale Bresciano, printed 1994, Teatro Carignano, Torino, 1995, directed by Sandro Sequi.

7 The close and fruitful relationship between two giants such as Agostino Lombardo ("Sapienza" Università di Roma) and Giorgio Strehler (Piccolo di Milano) around the translation and mise-en-scène of Shakespeare's Tempest is attested by their private correspondence and the multi-layered translations contained in (COLOMBO 2007).

8 The English Theatre Culture 1660-1737 research project based at Masaryk University (Brno, Czech Republic) aims at realizing exactly this meritorious enterprise by producing a substantial corpus of translations of Restoration dramas into Czech which might be ready for staging. In the programmatic words of the team animating this initiative, "The concept of dramaturgical translation, informed by theatre theory and practice, takes as its basis not the verbal component of the dramatic text but the social reality (human interaction) that underlies the dramatic situations that the dramatic text proffers. Practically, dramaturgical translation is based on close cooperation between the translator and dramaturgs, who refine its dramatic qualities - similar to the way in which new dramatic writing is an outcome of a close collaboration between the playwright and the commissioning dramaturg" (KRAJNÍK et al. 2019: 125, emphasis mine). 
if the responsibility for ensuring the performability of the target text may well be placed on to the other mediators involved in the process of intersemiotic transfer - director, actors, set designers, and so on -, it is however crucial for translators to be aware of the performativity which is inscribed in the word of drama, in its close network of aural, visual, kinesic suggestions. (SONCINI 2007: 276)

If one accepts Soncini's suggestion, it is even more surprising how little conscious attention the everlasting diatribe surrounding drama translation has received in the prefaces or in the note apparatuses of Italian academic translators of Restoration comedies. Even when producing very scholarly introductions and often presenting parallel texts, they conduct hardly any linguistic observation or analysis of translation issues beyond the level of single culture-specific references and lexicon. Their interpretations, always drawn on literary-critical or at most cultural approaches, do not fail to underline the linguistic texture and even the metalinguistic dimension of this specific genre. Nevertheless, except for an ever-present note on the significance of characters' names in Restoration comedy and the translator's ensuing decision on how to render them, Italian scholars barely engage in a thorough linguistic analysis, which might shed light on the performativity of the comedic text, or in a systematic reflection on translation cruxes, which inevitably occur even when producing a target text for the page, not for the stage.

Based on a personal translation experience of non-canonical comedies from the Restoration corpus, never before translated nor ever performed in Italy, ${ }^{9}$ the list of linguistic issues relevant to their understanding and affecting their translation is in fact quite long. In the context of the highly polysemiotic, multimodal and multimedia system embodied by drama, the verbal text represents one layer of communication, which enacts its entire semantic potential only when completed by performance. ${ }^{10}$ Yet, even merely in written form, it also exhibits the very complexity of any other phenomenon of communication, textuality or parole thus worth analysing with variational linguistics both in the source and in the target language:

- diachronic/diatopic variation in general:

- issues of standard and possible dialects

- at a morpho-syntactic level: e.g., the personal address pronouns

- at a lexical level: e.g., proverbs and idioms

9 Aphra Behn's Sir Patient Fancy (1678) was actually published with parallel texts, explicative notes to both the English text and the Italian translation, and an afterword largely dedicated to the discussion of the main linguistic features and translation issues (GRAZIANO 2003, 2008). The Committee, or the Faithful Irishman (1662, performed 1665) by Sir Robert Howard, and The Careless Lovers (1673) by Edward Ravenscroft still await their opportunity.

10 Cf. (KOWZAN 1975; ECO 1977; UBERSFELD 1977; RUFFINI 1978; ELAM 1980; LARTHOMAS 2001). The semiotic description of theatre has never been denied but has been enriched throughout the years by the inclusion of spectator and culture perspectives, following the same progress as in other branches of literary studies. 
- diastratic/diaphasic variation:

- specialized discourse/lexicon, used both in professional contexts (jargons) and in general conversation, both with and without a parodic/satiric function

- (im)politeness, from courtesy titles down to the entire dramatic dialogue

- idiolects portraying single characters

- diamesic variation (as an oral variety):

- phatic elements (e.g., cursing and swearing)

- textual variation (issues connected with the comic genre):

- wit and humour: witty/unwitty repartee

- historical/political reference

- sub-genres (e.g., farce)

- onomastics (e.g., names of character types) and toponomastics

- extra-corpus intertextuality (to the limit of plagiarism, as with Molière) and intracorpus (re-writing of same themes, scenes, character types, etc.).

Some of these issues are of course shared by any form of theatre, although some are specific to the drama of this historical period and to the comic genre in particular; others can be analysed at a single level of language variation, some impinging on more than one. All need to be projected on the one hand onto the diachronic dimension of late Early Modern English and on the other onto the prospect of possibly staging these comedies nowadays in either language. In other words, all these linguistic phenomena are to be placed in relation to stage and audience, to theatre pragmatics and to the effects of performativity/performability (including speakability) ${ }^{11}$ of theatrical language; moreover, in cases where stage and audience belong to a non-native language/culture, all levels listed above should be submitted to the choice and corresponding outcomes of adopting translation strategies (e.g., domesticating/foreignizing strategies).

Among the many levels of linguistic and translatological analysis allowed by Restoration comedy texts, the case of the second person address pronouns (you/thou) will be addressed in this article and their particular usage in Aphra Behn's Sir Patient Fancy because this topic offers the opportunity to deal with all three issues at stake:

1) the lack of a generalized, systematic and explicit reflection on linguistic and translatological issues on the part of the Italian translators, resulting in an extreme variety of solutions and even inconsistency within the same translated text;

2) conversely, the relevance of a proper historical-linguistic and pragmalinguistic analysis of the single comedic verbal text before proceeding to translation, especially when confronted with one of the notoriously major differences between English and Italian, i.e., the pronominal system; and

3) the impact of issues of genre, (im)politeness and theatre pragmatics on translator's choices.

11 See (SNELL-HORNBY 1988/1995; ESPASA 2000; SUH 2002) for a treatment of these specific concepts. 


\section{The address pronouns in history and in translation}

The personal pronoun system, being part of linguistic deixis and closely related to anaphoric reference, plays a fundamental role in theatre communication. Italian semiotician and English scholar Alessandro Serpieri highlighted the exploitation of deixis by the dramatic text in comparison with any other literary text in a ground-breaking article published in 1977, where he maintained that drama produces sense only in reference to a pragmatic context. In the theatre, both morphosyntax and rhetoric are subject to deixis, which articulates and conveys the meaning through the other linguistic levels and extra-linguistic codes involved, such as intonation, rhythm, proxemics, gestures, images, the very bodies of the actors/characters, etc. Through deixis, the fictional world of theatre is created, whereas the dynamics and interactivity of dramatic discourse is primarily based on the pronominal confrontation between an I and a YOU and set in a HERE and a NOW. In the context of a semiotic approach to the language of theatre, Segre (SEGRE 1984) concludes that deixis is exactly what permits the antinomy between written and staged text to be reconciled, since deictics allude to the mise-en-scène in the text and actually provide the support needed by the gestic code on the stage. ${ }^{12}$

Second person address pronouns in particular are a favourite case of social deixis when a distinction between $\mathrm{T} / \mathrm{V}$ is activated in the language, as it still was in English in the early modern times when you and thou coexisted to indicate the second person singular, before the standardized extension of you to singular and plural, and to formal and informal registers. The case of the English address pronouns has been indeed largely studied by historical linguistics, socio-linguistics and pragmalinguistics - and more recently revived by the line of (im)politeness scholarship - as specimens of politeness markers, revealing the degree of formality, familiarity and solidarity between the interlocutors. Moving from the assumption that dramatic dialogue is to an extent a reliable testimony of contemporary language use, research has been conducted primarily on the Shakespeare corpus or on single plays. The later stages of the evolution of the English language towards standardization have received much less scholarly attention. Nevertheless, discussions about what governs the early modern speaker choice of you vs. thou still produce significant differences. ${ }^{13}$

Generally speaking, it has been observed that the use is much more varied than what Brown and Gilman, who inaugurated the pragmatic approach, hypothesized in their early study on "The Pronouns of Power and Solidarity" (BROWN and GILMAN 1960). The simplified story is that as a norm thou/thee/thy, aside from being used to address God, would mark relationships between master and servant, parent and child, superior and inferior; you/yee/your was reserved for addresses among peer members of the up-

12 Serpieri himself continued writing extensively on the subject, often in cooperation with co-researchers such as Keir Elam (see VV. AA. 1981) and always with the fruitful contribution of his own experience as translator of the Shakespearian text and as collaborator to the mise-en-scène (see his late SERPIERI 2013).

13 Both previous research studies and the intricacy still entailed by the non-standardized use of second person pronouns in EME are reviewed in detail by (BUSSE 2002, esp. Chapter 2) and more recently, with a specific focus on (im)politeness in Shakespeare, by (DEL VILLANO 2018). 
per classes, including husband and wife (BARBER 1987), whereas thou/thee would be used among people of the lower classes (MULHOLLAND 1967). On the other hand, Quirk, introducing the idea of markedness, maintains that you is to be intended as the neutral form of the two - "not impolite", "not informal" - against which to check the wide variety of thou usage (QUIRK 1974). However, since early studies dating back to the nineteenth century, great fluctuation and freedom of use have always been noted, mainly due to sentimental involvement (friendship, male comradeship, or love) as opposed to respect, which were fully exploited in the theatre and by Shakespeare in particular (MAZZON 2003). Such flexibility, most often underlining characters' attitudes towards others, would certainly be accompanied on stage by proxemics, such as body posture and distance, gestures, tone of voice, etc. (PARTRIDGE 1969: 24).

Lastly, Busse's very thorough study on the Shakespeare corpus (BUSSE 2002) demonstrates that variation is connected to other factors, too, such as nominal co-occurrences in the discourse, prose or poetry texts and genre (with a remarkable predominance of you in prose and comedy), and even the context of a specific play. Yet Busse also admits to occurrences which remain unexplained, at least from our modern standpoint. At the end of the seventeenth century, still within a phase of incomplete standardization, you as a second person pronoun is quantitatively predominant (JOHNSON 1966), with women tending to use you both to convey respect and prestige (WALKER 2003) and servants not at all conforming to the use of thou as previously stated (BUSSE 2002). Consequently, shifting to thou is pragmatically and socio-linguistically significant, marked (BRUTI 2000). Among other reasons, the use of thou might emphasize character types as old or old-fashioned or out-fashioned: the relevance of being $\grave{a}$ la mode in Restoration times is well-known!

The comparative linguistic perspective on the issue cannot but reveal profound differences among languages and mark oscillations in scholars' attitudes towards their impact on translation. The above-mentioned 1960 study by Brown and Gilman, while tracing the socio-semantic evolution of the address pronouns from Latin to some modern European languages, categorize and underline the radical difference between the so-called "T/V languages" such as Italian, and languages such as Modern English. John Lyons's (LYONS 1980) structuralist approach to semantics notoriously came to identify this area of "simple grammatical distinction" as one of the classic cases of untranslatability, or at most of rough and inadequate translation, due to almost total incompatibility between two linguistic codes. And even if no scholar of Translation Studies would endorse such a strictly structuralist viewpoint nowadays - at least not after Roman Jakobson's (JAKOBSON 1959) seminal (and liberating!) contribution - there is no doubt that the question of the address pronouns remains a typical case study of the relativity or imperfection of translation between the grammatical and sociolinguistic dimensions of many languages if only in the European area, with a reverberation on the translation of dramatic discourse (ANDERMAN 1993, 1998, 2005; HORTON 1999).

Moreover, the comparison and translation of English and Italian are further complicated by the great instability of the second person pronoun usage in the early modern phase of the English language described above. Far from simplifying matters, the only 
apparent overlapping of the EME pair you/thou and the contemporary Italian one, voi/ $t u$, normally induces an unspoken choice in favour of the domesticating strategy which stabilises voi for polite/formal relations and $t u$ for confidential/familiar ones. After verifying the corpus of 24 book translations of the comedies since World War II (mine excluded), I found that this choice is made explicit only in one case (INNOCENTI 2009: 359) but never justified either by reference to the long-standing research and debate on the topic or by a discussion of what is to be considered a more or less distant/ close relation by modern parameters. Cases of very 'literal' translation, faithful to the source text fluctuation within the same conversation and by the same character, can also be traced (CERUTTI 2005): in this case the effect on the reader's ear is definitely foreignizing and, were the dialogues staged and not simply left on the page, even grating. Incidentally, there have been no attempts to discuss the viability of our current polite pronoun Lei: in fact, anachronistic as it might sound and transgressive of a wellestablished canon of historical translation, its adoption in the case of an extremely modernising tradaptation or dramaturgical translation would be worth considering. Instead, Italian translators of Restoration drama, even academic ones and even in recent times, overlook this issue completely, thus neglecting the pragmatic effect of their choices in the target text, and even avoid - or at least avoid sharing the results of - the necessary analysis of the source text.

\section{Aphra Behn's Sir Patient Fancy, an "unlabour'd farce"}

When I decided to translate Sir Patient Fancy, I inevitably chose to fit my translation in a tradition of academic/literary translations of Restoration plays. Nevertheless, I immediately realised I had to come to terms with the intrinsically theatrical quality of this play, with its performativity, if not its performability. This is a comedy about cuckoldry with a strong pro-Stuart political engagement (1678 marks the beginning of the "cursed plotting age", as Behn herself calls it in The Feign'd Curtizans). Not only is the cuckold an old hypochondriac, but he is a Citizen (a Cit), a recognisable and acknowledged version of Molière's malade imaginaire in a Puritan environment. Thus, first and foremost, the question of how relationships between sexes are played out in terms of address pronouns must be settled: how are husband and wife (Sir Patient and Lady Fancy), the adulterers (Lady Fancy and Wittmore) and the young couples (Lodwick and Isabella; Leander and Lucretia) to address each other to be credible in Italian? The Italian translator must necessarily stabilise and fix the use of the pronouns disregarding Early Modern English variation. My initial choice, as in many of the translations perused, was to extend voi to all the relationships between peers. And yet here was the first difficulty: if ever this strategy worked between the cuckold and his adulterer wife, how ridiculous and inconsistent would the use of voi between long-time lovers like Lady Fancy and Wittmore sound? They, who unashamedly alternate you/thou all along, both in public and in private!

As a rule, Sir Patient Fancy is no exception both to general use and to flexibility, and also to the more recent results obtained by means of computational studies. Sir 
Credulous Easy always addresses his footman Curry with thou and so does Sir Patient his younger daughter Fanny, who invariably reciprocates with you. Lady Fancy and Lady Knowell invariably use you; Isabella and Lucretia, the younger friends, do so as well, except in some cases in which the context indicates a register shift to colloquialism (Act I.i: "Thou maist lay thy Maiden-head up'n it") or nearness ("I hope thou art as well resolv'd for my Cozen Leander"; "Is't possible thou should have perceiv'd it already?"). The male friends, on the other hand, are very prone to using thou unless, as observable in Shakespeare also, one of them is hiding something from the others and so keeps his distance or expresses annoyance with the usual camaraderie. Thou often appears in the many Asides revealing the characters' secret thoughts or hostile feelings towards other characters. Lastly, as concerns the relationships between the sexes, again there are no exceptions: whereas the greatest variety is, as already observed, with Lady Fancy and her lover Wittmore, husband and wife say you to each other and so do the couples of young lovers - at least most of the time.

My translation approach to this issue was finally led by the comic subgenre to which Aphra Behn herself, a very self-conscious writer, ascribes her play. Having elsewhere echoed Dryden's and other authors' tirades against the farcical turn of the contemporary comic spirit (DORREGO 2019), in the Epilogue Behn exalts Sir Patient Fancy as an "unlabour'd farce" against the mania for more classicist dramatic rules. Thus, she somehow strengthens our idea that the force of the dramatic dialogue lies in its exquisitely performative potential. Therefore, I decided that the scenic impact of some verbal exchanges had to be reproduced in Italian: for example, if the adulterers had stuck to the polite voi, much fun would be lost in those scenes where, surprised by Sir Patient, they pretend to entertain a formal relationship and, vice versa, relapse into a confidential mode as soon as Sir Patient is unaware (e.g., Act II, first and last scenes; Act IV, ending of scene ii). I decided to mark these changes with the sudden pronominal shift between the confidential $t u$, which at this point had to be constantly used in private, and the formal voi, constantly used in public. I managed to obtain a similar theatrical and comic effect in the Italian version of the utterly farcical gag in the last scene of Act IV by the shift from a stable voi to a stable $t u$ on the part of Sir Patient, who, in a state of increasing drunkenness, is about to exact his marital duties from a terrified and disgusted Lady Fancy, herself busy hiding her gallant under her bed first, then under her night-gown. In this circumstance Sir Patient does not really use thou towards his wife but conjures up a series of hilarious terms of endearment which, collocated with you in English, would sound simply absurd with the Italian voi.

There is one more special circumstance in this play. It occurs when Behn herself stabilises the use of the pronouns with the evident aim of serving a dramatic strategy. In the end, this was the occurrence that made me feel authorized to do the same in Italian by adopting a radical domesticating strategy in support of dramatic coherence and efficacy. I am referring to the parallel scenes in Act III reproduced in the table below, scenes where the young lovers, Isabella and Lodwick - who, as we said, constantly address each other with you - happen to swap partners respectively with 
Wittmore and Lady Fancy by mistake, or rather because both couples have made their assignations at night.

Draws off, and discovers Lady Fancy in her Night-gown, in a Chamber as by the dark.

La. Fan. Oh the agreeable confusion of a Lover high with expectation of the approaching bliss! What tremblings between joy and fear possess me? All my whole Soul is taken up with Wittmore, I've no Idea's, no thoughts but of Wittmore, and sure my tongue can speak no other language, but his name.-Who's there?

Enter Maundy leading Lodwick.

Maun. Madam, 'tis I, and your expected Lover here - I put him into your hands, and will wait your Commands in the next Chamber. Exit Maundy.

Lod. Where are you my dearest Creature?

La. Fan. Here, - give me your hand, I'le lead you to those joys we both so long have sight for.

Lod. Hah! to joys? sure she doth but dally with me, - Aside.

La. Fan. Why come you not on my Dear?

Lod. And yet, why this admission? and i'th' dark too, if she design'd me none but vertuous Favours?-What damn'd temptation's this? [Aside.]

La. Fan. Are you bewitch'd, what is't that frights you?

Lod. I'me fixt, Death, was ever such a Lover? Just ready for the highest joys of Love, And like a bashfull Girl restrain'd by fear Of an insuing Infamy, [Aside.] -I hate to Cuckold my own Expectations.

La. Fan. Heavens! what can you mean?

Lod. Death, what's this, -sure 'tis not Vertue in me, -Pray Heaven it be not impotence!-Where got I this damn'd honesty which I never found my self master of till now? - why shou'd it seize me when I had least need on't? [Aside.]

La. Fan. What ails you? are you mad?-we are safe, and free as Winds let loose to ruffle all the Groves, what is't delays you then? Soft.

Lod. Pox o' this thought of Wife, the very name destroys my appetite,

Oh with what vigor I could deal my Love

To some fair lewd, unknown,

To whom I'de never made a serious vow! [Aside.]
Changes again to a Garden. Enter Isabella and Fanny in their Night-gowns. [...]

Enter Wittmore.

Witt. Who's there?

Isab. Speak low, who should it be but the kind fool her self who can deny you nothing, but what you dare not take?

Witt. Not take! what's that? hast thou reserves in store?

-Oh come and let me lead thee to thy Bed, Or seat thee on some Bank of softer Flowers, Where I may rifle all thy unknown store.

Isab. How! surely you're not in earnest?-Do you love me?

Witt. Love thee! by thy dear self all that my Soul adores,

I'me all impatient Flame! all over Love!

-You do not use to doubt, but since you doe, Come, and I'le satisfy thy obliging fears, And give thee proofs how much my Soul is thine, I'le breath it all a-new into thy bosom, On thou art fit for the transporting Play, All loose and wanton, like the Queen of Love When she descends to meet the Youth in shades.

Isab. And are you Sir in earnest? can it be?

Witt. That question was severe, what means my Love[?]

What pretty art is this to blow my flame, Are you not mine? did we not meet $t^{\prime}$ injoy? I came not with more vigorous eager hast[e], When our first Sacrifice to Love we paid, Than to perform that Ceremony now. Come do not let the Sacred Fire burn out Which only was prepar'd for Love's rich Altar, And this is the Divine, dark, silent Minute.- Goes to lead her off.

Isab. Hold Ravisher, and know this sawcy Passion Has render'd back your interest. Now I hate ye, And my Obedience to my Father's will Shall marry me to Fain-love, and I'le despise ye. Flings from him. 
La. Fan. Tell me the Mystery of this sudden coldness? have I kept my Husband in Town for this? Nay, perswaded him to be very sick to serve our purpose, and am I thus rewarded!-ungrateful man!

Lod. Hah, -'tis not Isabella's voice, -your Husband say you? -

Takes hold greedily of her hand.

La. Fan. Is safe, from any fear of interrupting us. Come-these delays do ill consist with Love And our desires; at least if they are equal.

Lod. Death 'tis the charming Mother! What lucky Star directed me to night! [Aside.]

O my fair dear dissembler, let us haste To pay the mighty Tribute due to Love.

La. Fan. Follow me then with careful silence, -for Isabella's Chamber joyns to this, and she may hear us.

Lod. Not Flowers grow, nor smooth streams glide away,

Not absent Lovers sigh, nor breaks the day

More silently than I'le those joys receive,

Which Love and Darkness do conspire to give.

Exeunt.
Witt. Hah! Isabella! Death I have made sweet work, -stay gentle maid, -she'l ruin all if she goe-stay-she knew me, and cunningly drew me to this discovery; l'le after her and undeceive her.

Runs after her.

Studies from the 1960s on the structure of Restoration theatres acknowledged the possibility of darkening the stage almost completely on the evidence of stage directions such as "Sink lamps" (BURTON 1960). However, later scholars (HOLLAND 1979; STYAN 1986) excluded this possibility while advancing a less naturalistic interpretation of the relationship between performance, scenery and audience. The verbally created expectation of darkness would be scenically supported by performance in the upstage, i.e., by physically distancing the actors from the audience and thus loosening that intimate relationship of identification normally established in this kind of theatre by performance on the forestage. Thus, the stage direction preceding the first scene, which describes the setting "as by the dark", confirmed in the second by mention of the night-gowns, indicates the typical discovery scene performed in the upstage. ${ }^{14}$

In any case, the result is that the dramatic action seems to rely totally on words, specifically on the personal pronouns, complying with a strategy of confusing identities and delaying dénouement. Lodwick, addressed with constant you by Lady Fancy, as Isabella would have done, takes a long time to solve the puzzle of such unexpected, explicit sexual advances and to unveil the real identity of his one-night mistress. Isabella instead, immediately confronted by too confidential a thou from Wittmore, whom she

14 For interesting remarks on the role of stage directions between drama text and its performance, see (DILLON 1994; TOTZEVA 1995). Incidentally, discovery scenes were used by Behn more than by any other author of the period both for night scenes and situations involving dressing, undressing and bedrooms and to ensure spectacle (as in the pageant of the elephant in this same play). 
believes to be Lodwick, recoils in disgust from what she experiences as verbal sexual harassment. And yet, Wittmore uses thou in connection with very poetic, incredibly complimentary love language (almost a revisiting of the Song of Songs). One could classify this talk as "Positive Politeness" in Brown and Levinson's terms (BROWN and LEVINSON 1978/1987), but in the context of this specific scene the effect is exactly the opposite. The audience likewise would be induced to share the characters' misapprehension either by the change in the lighting, or by the actors' distant position on the scene, or by a sort of suspension of disbelief; but mainly, in my opinion, by listening to an unusually constant distribution of the address pronouns.

The outcome of my translation choices in these two scenes was doomed to varying degrees of success. Having opted for voi between the young lovers all along the play, Isabella feels just as abused by Wittmore - believed to be Lodwick - when he addresses her with $t u$ from the very beginning. Thus, the second scene of mistaken identity works out the same in Italian and in English. Not so the first scene, however: being a private encounter between Wittmore and Lady Fancy, the internal consistency of my translation choices imposes that the two adulterers use $t u$. Consequently, Lodwick's prolonged delusion, favoured by Lady Fancy's sustained use of you in English, is replaced in Italian by an immediate perception that it cannot be Isabella, that something strange is going on, even before Lady Fancy's reiterated advances. Lodwick's puzzlement in the Italian version can only revolve about the true identity of his interlocutor but not around her not being Isabella: possibly, to respect verisimilitude, the scene would even do with some trimming in a hypothetical Italian mise-en-scène. Thus, the asymmetric effect obtained by Behn in these two scenes by stabilising the distributive use of the English address pronouns is replaced by inevitable symmetry in Italian and by quite a different impact on both characters and audience: immediate surprise and incredulity in both cases rather than a delayed - and comic - shock of recognition in the first.

Something is gained and something is lost (as ever in the translation process), the sole compensation being that the translator knows and shows awareness of the game being played. I cannot but side and conclude with Horton's remarks that

pronominal choice presupposes a careful analysis of the dynamics of the text, and results in an explicitation of the attitudinal nuances of the original. In both cases, the process of translation implies a re-encoding based on the translator's individual conception of the source texts. The issue under discussion thus emerges as an archetypal feature of literary translation, showing how the latter manipulates texts by opening up some interpretive possibilities and closing down others. (HORTON 1999: 53) 


\section{Bibliography}

ANDERMAN, Gunilla M. 1993. Untranslatability: The Case of Pronouns of Address in Literature. Perspectives. Studies in Translation Theory and Practice 1 (1993): 1: 57-67.

ANDERMAN, Gunilla M. 1998. Drama Translation. In Mona Baker (ed.). Routledge Encyclopedia of Translation Studies. London: Routledge, 1998.

ANDERMAN, Gunilla M. 2005. Europe on Stage: Translation and Theatre. London: Oberon Books, 2005.

BARBER, Charles. 1981. You and thou in Shakespeare's Richard III. Rep. In Vivian Salmon and Edwina Burness (eds.). A Reader in the Language of Shakespearean Drama. Amsterdam: John Benjamins, 1981: 163-179.

BASTIN, George L. 1998. Adaptation. In Mona Baker (ed.). Routledge Encyclopedia of Translation Studies. London: Routledge, 1998.

BIGLIAZZI, Silvia, Peter KOFLER and Paola AMBROSI. 2013. Introduction. In Theatre Translation in Performance. New York/London: Routledge, 2013: 1-26.

BROWN, Penelope and Stephen C. LEVINSON. 1978/1987. Politeness. Some Universals in Language. Cambridge: Cambridge University Press, 1978/1987.

BROWN, Roger W. and Albert GILMAN. 1960. The Pronouns of Power and Solidarity. In Thomas A. Sebeok (ed.). Style in Language. Cambridge, Mass.: The MIT Press, 1960: 253-276.

BRUTI, Silvia. 2000. Address Pronouns in Shakespeare's English: A Re-appraisal in Terms of Markedness. In Dieter Kastovsky and Arthur Mettinger (eds.). The History of English in a Social Context: A contribution to historical sociolinguistics. Berlin/New York: Mouton de Gruyter, 2000: 25-51.

BURTON, Ernest J. 1960. The British Theatre 1100-1900. London: Herbert Jenkins, 1960.

BUSSE, Ulrich. 2002. Linguistic Variation in the Shakespeare Corpus. Morpho-syntactic Variability of Second Person Pronouns. Amsterdam-Philadelphia: John Benjamins, 2002.

CANFIELD, Douglas. 1997. Tricksters and Estates. Lexington: The University Press of Kentucky, 1997.

CANFIELD, Douglas. (ed.). 2001. The Broadview Anthology of Restoration and Early EighteenthCentury Drama. Peterborough, Ont.: The Broadview Press, 2001.

CERUTTI, Tony (ed.). George Etherege, L'uomo alla moda, ovvero Sir Fopling Flutter. In Paolo Bertinetti (ed.). La commedia inglese della Restaurazione e del Settecento. Napoli: Liguori, 2005.

COLOMBO, Rosy (ed.). 2007. William Shakespeare Agostino Lombardo Giorgio Strehler. La Tempesta tradotta e messa in scena. Roma: Donzelli, 2007.

DEL VILLANO, Bianca. 2018. Using the Devil with Courtesy. Shakespeare and the Language of (Im) Politeness. Bern: Peter Lang, 2018.

DILLON, Janette. 1994. Is There a Performance in This Text?. Shakespeare Quarterly 45 (1994): 1: 74-86.

DORREGO, Jorge Figueroa. 2019. 'Dwindling down to Farce'?: Aphra Behn's Approach to Farce in the Late 1670s and 80s. Journal of English Studies 17 (2019): 127-147.

ECO, Umberto. 1977. Semiotics of Theatrical Performance. The Drama Review 21 (1977): 1: 107117.

ELAM, Keir. 1980. The Semiotics of Theatre and Drama. London: Methuen, 1980.

ESPASA, Eva. 2000. Performability in Translation: Speakability? Playability? Or Just Saleability?. In Carole-Anne Upton (ed.). Moving Target: Theatre Translation and Cultural Relocation, Manchester: Saint Jerome, 2000: 49-62. 
FERNANDES, Alinne Balduíno Pires. 2010. Between Words and Silences: Translating for the Stage and the Enlargement of Paradigms. Scientia traductionis 7 (2010): 120-133.

GRAZIANO, Alba (ed.). 2003. Aphra Behn. Sir Patient Fancy. Viterbo: Sette Città, 2003.

GRAZIANO, Alba. 2008. Translating Aphra Behn's Plays into Italian: The Case of Sir Patient Fancy. In Annamaria Lamarra, and Bernard Dhuicq (eds.). Aphra Behn in/and Our Time. Paris: Les Éditions d'En Face, 2008: 118-129.

HOBBY, Elaine. 2007. Introduction: Prose of the Long Restoration (1650-1737). Prose Studies 29 (2007): 1: 1-3.

HOLLAND, Peter. 1979. The Ornament of Action. Cambridge: Cambridge University Press, 1979.

HORTON, David. 1999. Social Deixis in the Translation of Dramatic Discourse. Babel 45 (1999): 1: 53-73.

INNOCENTI, Loretta (ed.). 2009. William Wycherley. La moglie di campagna. Venezia: Marsilio, 2009.

JAKOBSON, Roman. 1959. On Linguistic Aspects of Translation. In Reuben A. Brower (ed.). On Translation. Cambridge, Mass.: Harvard University Press, 1959: 232-239.

JOHNSON, Anne C. 1966. The Pronoun of Direct Address in Seventeenth-century English. American Speech 41 (1966): 261-269.

KOWZAN, Tadeusz. 1975. Littérature et spectacle. The Hague: Mouton, 1975.

KRAJNÍK, Filip, Anna MIKYŠKOVÁ, Klára ŠKROBÁNKOVÁ, Pavel DRÁBEK and David DROZD. 2009. English Restoration Theatre in Czech: An Ongoing Research Project Conducted at the Department of English and American Studies and the Department of Theatre Studies in Brno. Theory and Practice in English Studies 8 (2009): 1: 123-127.

LARTHOMAS, Pierre. 2001. Le langage dramatique. Sa nature, ses procédés. Paris: Quadrige/PUF, 2001.

LYONS, John. 1980. Pronouns of Address and Solidarity in Anna Karenina: The Stylistics of Bilingualism and the Impossibility of Translation. In Stephen Greenbaum, Geoffrey Leech, and Jan Svartvik (eds.). Studies in English Linguistics for Randolph Quirk. London/New York: Longman, 1980: 109-122.

MAZZON, Gabriella. 2003. Pronouns and Nominal Address in Shakespearean English: a Socioaffective Marking System in Transition. In Irma Taavitsainen and Andreas H. Jucker (eds.). Diachronic Perspectives on Address Term Systems. Amsterdam/Philadelphia: John Benjamins, 2003: 223-250.

MULHOLLAND, Joan. 1967. Thou and you in Shakespeare: A Study in the Second Person Pronoun. Rep. in Vivian Salmon, and Edwina Burness (eds.). A Reader in the Language of Shakespearean Drama. Amsterdam: John Benjamins, 1981: 153-161.

NIKOLAREA, Ekaterini. 2002. Performability versus Readability: A Historical Overview of a Polarization in Theatre Translation. Translation Journal 6 (2002): 4. Available online at http:// www.bokorlang.com/journal/22theater.htm (last accessed Nov. 2020).

PARTRIDGE, Astley C. 1969. Tudor to Augustan English, A Study in Syntax and Style from Caxton to Johnson. London: Deutsch, 1969.

QUIRK, Randolph 1974. The Linguist and the English Language. London: Edward Arnold, 1974.

RANDALL, Dale B. J. 1995. Winter Fruit: English Drama, 1642-1660. Lexington: The University Press of Kentucky, 1995.

RUFFINI, Franco. 1978. Semiotica del testo. L'esempio teatro, Roma: Bulzoni, 1978.

SEGRE, Cesare. 1984. Teatro e romanzo. Torino: Einaudi, 1984. 
SERPIERI, Alessandro. 1977. Ipotesi teorica di segmentazione del testo teatrale, Strumenti critici 11 (1977): 32-33: 90-137.

SERPIERI, Alessandro. 2013. Semantics and Syntax in Translating Shakespeare. In Silvia Bigliazzi, Peter Kofler, and Paola Ambrosi (eds.). Theatre Translation in Performance. New York/London: Routledge, 2013: 50-60.

SNELL-HORNBY, Mary. 1988/1995. Translation Studies: An Integrated Approach. Amsterdam/ Philadelphia: John Benjamins, 1988/1995.

SONCINI, Sara. 2007. Intersemiotic Complexities: Translating the Word of Drama. In Marcella Bertuccelli Papi, Gloria Cappelli and Silvia Masi (eds.). Lexical Complexity: Theoretical Assessment and Translational Perspectives. Pisa: Plus, 2007: 271-278.

STYAN, John L. 1986. Restoration Comedy in Performance. Cambridge: Cambridge University Press, 1986.

SUH, Joseph Che. 2011. The Performability and Speakability Dimensions of Translated Drama Texts: The Case of Cameroon. inTRAlinea 13 (2011). Available online at http://www.intralinea.org/archive/article/1671 (last accessed Nov. 2020).

TOTZEVA, Sophia. 1995. Das theatrale Potential des dramatischen Textes: Ein Beitrag zur Theorie von Drama und Dramenübersetzung. Tübingen: Gunter Narr, 1995.

UBERSFELD, Anne. 1977. Lire le théâtre. Paris: Editions Sociales, 1977.

VV. AA. 1981. Drama, Theater, Performance: A Semiotic Perspective. Poetics Today 2 (1981): 3.

WALKER, Terry. 2003. You and thou in Early Modern English Dialogues: Patterns of Usage. In Irma Taavitsainen, and Andreas H. Jucker (eds.). Diachronic Perspectives on Address Term Systems. Amsterdam-Philadelphia: John Benjamins, 2003: 309-342. 


\section{Prof. Alba Graziano}

Department of Humanities, Communication and Tourism,

Tuscia University,

Via Santa Maria in Gradi 4, 01100 Viterbo, Italy

graziano@unitus.it

Alba Graziano is currently Professor of English Language and Translation. As a scholar of English Literature, she has researched in the $18^{\text {th }}$ and $19^{\text {th }}$ centuries, particularly the novel, and published on authors such as Behn, Addison, Swift, Hume, Beckford, the Brontës, Dickens, George Eliot, Meredith, some of whose works she has also translated focusing on cultural, literary and historical-linguistic questions. More recently she has studied non-literary genres (e.g., marginal texts like menus and public directives) and theatre textuality with a view on translation. She has been engaged for many years in teacher training initiatives (among which the Content and Language Integrated Learning approach) and European projects dedicated to adult education, digital competences and second language acquisition, contributing scientific articles on these issues. She directs the journal Fictions. Studi sulla narratività (Fabrizio Serra) since 2002, the series 'Anglia', which publishes literary translations with parallel text, and 'Dopo Babele', including studies on applied linguistics and language teaching (both Sette Città). 